Frontiers: The Interdisciplinary Journal of Study Abroad

(C) 2021 Hannah Vann Nabi and Pam Estes Brewer

The work is licensed under the Creative Commons Attribution-NonCommercial-NoDerivatives

4.0 International License.

Volume 33, Issue 2, pp. 17-34

DOI 10.36366/frontiers.v33i2.555

FORUM

ON EDUCATION

ABROAD

\title{
Communicating Ethical Engagement
}

Abroad: A Content Analysis of Service-

Learning Study Abroad Third-Party

\section{Provider Websites}

Hannah Vann Nabi ${ }^{1}$, Pam Estes Brewer ${ }^{1}$

\begin{abstract}
This article shares the results of a study that analyzed the website content of eight thirdparty providers that offer service-learning study abroad programs to college students. The study looked specifically at the information about service-learning projects and how host communities, community partners, and target populations are portrayed or represented within that content. Data are analyzed through the lens of two ethical guidelines for international service-learning defined by The Forum on Education Abroad: prioritization of human dignity and community autonomy; and recognizing the risk of paternalism, exploitation, and neocolonial behavior. The findings of this study serve to provide baseline data about the public information shared by international service-learning program providers about service projects and partners as well as insights into how organizations that produce web content about service-learning partnerships can design information that meets ethical standards related to upholding dignity, respecting autonomy, and challenging paternalism.
\end{abstract}

\section{Keywords:}

international service-learning, third-party providers, communicating ethical engagement, content analysis

\section{Introduction}

As higher education institutions in the United States become increasingly focused on preparing their students for active and engaged citizenship in a global community, 
international learning experiences are at the forefront of these globalization efforts. However, many institutions lack the resources to provide a broad enough selection of programs to match students' diverse interests, financial resources, and academic pathways. Over the past two decades, an industry of for-profit and non-profit third-party providers has emerged to fill this gap, and colleges and universities partner with providers to offer their students international education experiences of all types (Heyl, 2011). Providers can offer localized expertise, in-country supports, and collective bargaining power that many institutions cannot afford to match (Chieffo \& Spaeth, 2017). Niche international experiences, such as international service-learning, are growing in popularity as well. Providers' localized expertise is particularly valuable for international service-learning because their language fluency and partner contacts for service projects enable them to facilitate international service-learning experiences for U.S. faculty and students. Despite higher education's growing reliance on providers, however, these providers are still a largely self-regulated industry.

A challenge for higher education institutions that encourage their students and faculty to work with providers is quality control (Rhodes, Loberg, \& Hubbard, 2014). This concern becomes more complex when a service-learning component is introduced into the study abroad experience. Although higher education institutions have established their own practices for vetting providers on issues of academic rigor, safety, and risk management, there are additional factors to be considered for service-learning study abroad programs. The types of service, required hours of service, relevance of service to the course, integration of reflection and critical discourse about the service, and ethical considerations of impact on the local community are all important considerations for designing high-quality service-learning experiences (“Guidelines,” 2018).

The Forum on Education Abroad, as the designated standards development organization for the field of international education, has developed a Quality Improvement Program (QUIP) that recognizes participating institutions and organizations for meeting The Forum's Standards of Good Practice (“Standards," 2015). Only 24 institutions or organizations have received recognition to date (QUIP: Recognition, n.d.). Of those recognized organizations, approximately half are third-party program providers, a fact that bodes well for the reach of The Forum beyond higher education institutions. The QUIP recognition currently applies to international education in general and does not offer special designations of excellence for specialized programs like international servicelearning or global internships. The Forum does, however, recognize that international service-learning and community engaged learning require additional considerations, and they offer two supplements to the Standards of Good Practice document to support best practices: the Guidelines for Community Engagement, Service-Learning, and Volunteer Experiences Abroad (2018) and Guidelines for Undergraduate Health-Related Experiences Abroad (2018).

To gauge adoption of the Standards among international education professionals, The Forum on Education Abroad issues a "State of the Field" report every two years with survey data from Forum members. The 2017 report revealed that $79 \%$ of all respondents agreed or strongly agreed that the Standards are being used to shape policies on education abroad at their institutions or organization, and $64 \%$ of all respondents agreed or strongly agreed that the Code of Ethics was used to inform decisions regarding policy on education abroad (“State of the Field 2017," 2018). 
Despite attempts to grow the Quality Improvement Program (QUIP), its scope is still too limited to offer relief to higher education professional staff from the challenge of vetting third-party providers. The survey data about adoption of the Standards of Good Practice iare encouraging, but unfortunately, the responsibility of ensuring a third-party provider is delivering safe, quality educational experiences abroad rests on the shoulders of the college and university staff in international education offices (Kurtzman, 2017). For colleges and universities that want to provide international service-learning experiences, the vetting process can be even more time consuming because of additional questions about the service project, the host community, and integration into the curriculum. As Hartman and Kiely contend, the growing emphasis on globalization and civic engagement in higher education encourages professional staff and faculty to "turn to third-party providers in the international education market who often know a great deal about developing trips abroad but have little or no background in community-driven service, community-university partnership, and other nuances of community-engaged work" (2014). With 57\% of respondents to The Forum's 2017 survey reporting that they establish community service and/or service-learning projects to address social consequences in their education abroad programming, developing more efficient ways of evaluating the quality of third-party providers' international service-learning becomes more pressing ("State of the Field 2017,” 2018).

Although there are a variety of ways for providers to approach ethical servicelearning, it is not enough for third-party providers to do ethical engagement in partnership development and program implementation. They must also communicate ethical engagement to their participants, community partners, and institutional partners in the information they develop about their programs. The way they represent their programs, partners, and host communities can provide an ethical framework for presenting information about their service-learning programs.

In order to understand how third-party providers are communicating about their service-learning study abroad programs, this research seeks to answer the following questions:

1. What kind of information are third-party providers sharing about service-learning programs, projects, and partners on their websites?

2. How does the language they use to describe service partners, target populations, and host communities align or not align with guidelines on ethical engagement?

This article discusses the results of a study that analyzed the website content of eight thirdparty providers that offer service-learning study abroad programs to college students. The study looked specifically at the information about service-learning projects and community partners, collecting information on the categories of information provided about servicelearning projects and how host communities, community partners, and target populations are portrayed or represented within that content. Data are analyzed through the lens of two ethical guidelines for international service-learning:

- Prioritize human dignity and community autonomy such that educational agendas of the student or the home institution are not prioritized over community safety, autonomy, and dignity. 
- Recognize the risk of paternalism, exploitation, and neocolonial behavior on behalf of institutions/organizations from resource-rich environments when engaging with partners in low material resource settings (Guidelines, 2018).

The findings of this study serve to provide baseline data about the public information shared by international service-learning program providers about service projects and partners as well as insights into how organizations that produce web content about servicelearning partnerships can design information that meets ethical standards related to upholding dignity, respecting autonomy, and challenging paternalism.

\section{Literature Review}

This literature review includes searches in Google Scholar and 219 Ebscohost databases using combinations of the following keywords: international, global, servicelearning, study abroad, international education, third-party program provider, international education provider, and program administration. Publications recommended on the Campus Compact Global Service Learning Research webpage and The Forum for Education Abroad website were also considered.

Much of the literature on international service-learning focuses on student motivations and experiences, pedagogy, and ethical engagement with host communities (Dixon, 2015). In the searches for this literature review, only two articles returned that examine the role of third-party providers in administering study abroad programs (HainsWesson, 2017; Hains-Wesson \& Appleby, 2017). Neither the Hains-Wesson nor HainsWesson \& Appleby articles address service-learning as a component of study abroad. HainsWesson \& Appleby identify several recommendations for establishing effective and inclusive collaborative partnerships between universities and program providers. In a separate article, Hains-Wesson responds to the call for regulation of the third-party provider industry in Australia by likening the current quality crisis to previous Australian industry reform in real estate, boating, and automotive industries.

Despite the dearth of research into third-party providers, there has been significant caution and criticism about the dangers of international volunteerism. Critics have identified several areas of concern including the potential for international volunteerism to reinforce stereotypes about global inequalities, broader impacts on host communities that erode the health and well-being of people served in those communities, and the ethical obligations of organizations that participate in international service to examine organizational responsibility in perpetuating negative impacts in both students and host communities (Goodwin, 2015; Steele \& Dredge, 2017; Hernandez-Maskivker, Lapoint, \& Aquino, 2018; Melles, 2018; Bamber \& Pike, 2013).

This conversation about ethical global engagement has permeated popular culture as well. A growing awareness in young adults of the role visual media plays in constructing narratives about power and privilege in developing countries has resulted in the emergence of counter narrative initiatives on social media platforms. Campaigns like Humanitarians of Tinder on Tumblr and Barbie Savior on Instagram poke fun at the practice of sharing images online that blur the lines between service, tourism, and exploitation and propagate myths about people and problems in developing countries (Schwarz \& Richey, 2019). In a study published in 2019, Sin and He discovered that these types of satirical campaigns may be succeeding in raising some students' consciousness 
about the types of photos they post and how they depict their service abroad (Sin \& He, 2019).

As noted previously, in 2018, The Forum on Education Abroad issued Guidelines for Community Engagement, Service-Learning, and Volunteer Experiences Abroad, the first guide to international service-learning program design. The document, which serves as a companion to the Standards of Good Practice (2015), outlines nine guidelines that address each aspect of international service-learning program design. A central theme in this document is a commitment to the preservation of human dignity.

\section{Methods}

A content analysis methodology was selected for this study because it supports both qualitative and quantitative data collection. This section includes a description of the content included in the study, the sample selection process, and the coding strategy. The following research questions framed the study design:

1. What kind of information are third-party providers sharing about service-learning programs, projects, and partners on their websites?

2. How does the language they use to describe service partners, target populations, and host communities align or not align with guidelines on ethical engagement?

This study was approved as exempt by the Institutional Review Board of Mercer University on October 31, 2019 (H1910278).

\section{Content Analysis}

Third-party provider websites are designed to appeal to multiple audiences, ranging from potential student recruits to parents to university faculty and staff who are vetting international education programs. With such a broad audience, providers use their websites to communicate information about their organizations, the countries in which they operate, the types and durations of programs available, customer reviews and feedback, host communities, and pricing. The information serves to market to students and parents as well as demonstrate professionalism and reliability to higher education institutions. As a result, website content can reveal some important information about third-party providers' values, operations, and practices.

Although visitors to a provider website are typically encouraged to complete a form or contact the provider directly for program details, providers also need to offer enough public information to generate interest and trust. Considering that the average website user spends just 15 seconds reviewing the website before deciding whether or not it contains relevant or valuable information, providers must balance protecting proprietary information with offering enough detail to capture user interest (Hail, 2014). A content analysis can identify which key information is present (or absent) as well as provide insight into how users may interpret existing content. With the persistent criticisms about the role of international volunteerism in reinforcing global inequalities, it becomes critical for providers to understand how their internet content can shape customers' perceptions of the quality of international service-learning experiences.

This study includes content analysis of provider website content. Website content on the following pages were reviewed: 
- About Us (and related subpages) were included for the information they provide about providers' mission and values. In reviewing websites in preparation for sample selection, it was noted that some providers include information pertinent to service-learning and community engagement in the About Us sections of their websites.

- Service-Learning Programs overview page, if available, can be used by providers to share information about organizational approaches to service-learning or community engagement and principles that underpin program design.

- Webpages for specific service-learning programs, if available, provide the most specific information about a program, project, and host community.

If providers included reviews or testimonials for service-learning programs on the target webpages, that content was also included in the analysis.

\section{Sample Selection}

The source of the sample for this study was the public members list published by The Forum on Education Abroad. The list was accessed in September 2019. The 816 organizational members were first classified by organization type: higher education institution, consortium, professional association, government agency, logistics management company, third-party program provider, and other. Working within the list of identified third-party provider member organizations, the websites were reviewed to determine if the provider listed "service-learning" under its program categories or program search options. Providers that listed only "volunteer" or "service" without the curricular component (learning) were excluded. Although many provider websites may mention the option to customize volunteer or service opportunities, the presence of servicelearning as a program category suggests an intentional design as a service-learning program and a level of sustainability of program offerings over time which is why the criteria were limited to this distinction. Finally, the organizations were classified by whether or not they offer programs directly to students or only for faculty-led program support; only providers offering direct enrollment to students were included in the sample. A total of eight member organizations met these criteria. The information for categorization was collected from the eight members' websites between September 21 October 1, 2019. The online content for analysis was accessed in October 2019.

\section{Coding Strategy}

The coding process consisted of an initial reading of all content to gain familiarity with information and design format. Then the content was read a second time and coded with the unit of analysis at the sentence level. The content that was included in the coding was then separated from the broader sample and read a third time for a second round of coding using words or phrases as the unit of analysis.

Content was coded using the inductive method. An initial coding scheme was developed by coding a representative $10 \%$ sample of the available content, using sentences as the unit of analysis. The categories of information types were identified from that data set, and the remaining content sample was coded using the following identified categories:

- Admission criteria

- Benefit to community partners 
- Community partner information

- Context of service project

- Learning goals

- Organization mission and values

- Project description

- Project goals

- Student training/preparation for service project

After the first coding phase to identify the types of information used to describe service projects, the content of those codes was analyzed a second time to identify language used to describe service partners, target populations, and host communities. The unit of analysis for the second phase of coding was words and phrases. Two categories emerged from this exercise:

- Language that characterizes the nature of service partnerships, and

- Language that describes target populations.

Analysis of the second coded set for language was based on ethical guidelines from The Forum on Education Abroad's Guidelines for Community Engagement, Service-Learning, and Volunteer Experiences, specifically two of the guidelines on ethics in community engagement experiences:

- Prioritizing human dignity and community autonomy, and

- Recognizing the risk of paternalism, exploitation, and neocolonial behavior (2018, pp. 16).

\section{Results}

The data outlined in these results were collected with the goal of answering the following research questions:

1. What kind of information are third-party providers sharing about servicelearning programs, projects, and partners on their websites?

2. How does the language they use to describe service partners, target populations, and host communities align or not align with guidelines on ethical engagement?

It is important to note that multiple webpages were analyzed for each of the eight provider websites (see Table 1). Of those websites, six of the providers offer individual webpages for each service-learning program. Although each provider uses a template of information that supports consistency of information across different programs, the level of detail does vary within specific provider websites. The findings reported in this paper are general to the overall provider website, and the presence of information counted may not appear on every provider's individual program page.

Using inductive coding, the following categories emerged as types of information included in the webpage descriptions of the service component of service-learning study abroad programs:

- Articulating the learning goals for students 
- Specifying admission or selection criteria for the service-learning program

- Describing plans to orient or train students for the service-learning project

- Referencing the role of community partner(s), either by name or in general

- Describing service project tasks

- Articulating the benefit of the service project to the community partner(s) or host community

- Describing the context of the service, either as offering a history of the community or defining the need(s)

- Articulating goals or outcomes of the service project

Table 1. List of the eight third-party providers included in this study along with the total number of webpages analyzed for each provider.

\begin{tabular}{|c|c|c|}
\hline $\begin{array}{c}\text { Third-party } \\
\text { Provider }\end{array}$ & $\begin{array}{c}\text { Total Pages } \\
\text { Analyzed }\end{array}$ & $\begin{array}{c}\text { Total Program } \\
\text { Pages Analyzed }\end{array}$ \\
\hline Provider A & 10 & 8 \\
\hline Provider B & 10 & 9 \\
\hline Provider $\mathrm{C}$ & 8 & 7 \\
\hline Provider D & 16 & 14 \\
\hline Provider E & 2 & 0 \\
\hline Provider $\mathrm{F}$ & 2 & 0 \\
\hline Provider $\mathrm{G}$ & 15 & 14 \\
\hline Provider $\mathrm{H}$ & 7 & 6 \\
\hline Total & 70 & 58 \\
\hline
\end{tabular}

\section{Organizational Values}

Table 2. Organizational values matched with the providers that include the values in their About Us webpage content

\begin{tabular}{|c|c|c|c|c|c|c|c|c|}
\hline \multirow[b]{2}{*}{ Values } & \multicolumn{8}{|c|}{ Providers } \\
\hline & $\mathrm{A}$ & $\mathrm{B}$ & $\mathrm{C}$ & $\mathrm{D}$ & $E$ & $\mathrm{~F}$ & $\mathrm{G}$ & $\mathrm{H}$ \\
\hline Collaboration & $x$ & $x$ & & & & & & \\
\hline Cultural Exchange & $x$ & $x$ & $\mathrm{x}$ & $x$ & $x$ & $x$ & $x$ & $\mathrm{x}$ \\
\hline Diversity \& Inclusion & $x$ & $x$ & & & $x$ & $x$ & $x$ & $\mathrm{x}$ \\
\hline Empathy & $\mathrm{x}$ & $x$ & $\mathrm{x}$ & $x$ & & & & $\mathrm{x}$ \\
\hline Empowerment & & & & $x$ & & $x$ & $x$ & \\
\hline Environmentally Conscious & & & & & & $x$ & $x$ & $\mathrm{x}$ \\
\hline Ethical Practice & $x$ & $x$ & & $x$ & & $x$ & $x$ & $\mathrm{x}$ \\
\hline Reciprocity \& Mutual Benefit & & & & & $x$ & $x$ & & $\mathrm{x}$ \\
\hline Safety & $\mathrm{x}$ & $x$ & & & $\mathrm{x}$ & $x$ & $\mathrm{x}$ & \\
\hline Social Responsibility & & & & & & $x$ & $x$ & $\mathrm{x}$ \\
\hline Sustainable Development & & & & $x$ & & & & \\
\hline
\end{tabular}

Information in the "About Us" section of websites was coded for organizational values. Eleven values were coded with cultural exchange appearing in content for all eight 
providers. Diversity \& inclusion, empathy, ethical practice, and safety were the other most popular organizational values articulated in the analyzed content. The list of values and their associated providers are available in Table 2.

\section{Articulating Learning Goals}

Coding revealed ten different learning goals shared across two or more providers. Only one provider, Provider G, did not list any learning goals in the content included in this analysis. The full list of learning goals is available in both Table 3 and Table 4 .

Goals relating to intercultural competency spanned the broadest number of servicelearning programs, followed by goals supporting professional skill development (see Table 3). Goals related to an increased understanding of an individual's social responsibility spanned the greatest number of providers, appearing in content for Providers A, B, D, E, and F (see Table 4). Global citizenship was also a recurring theme in the learning goals for half of the providers.

Of the seven providers that mention learning goals, two providers - E and F - list just one goal each, both related to social responsibility. It is worth noting that these providers did not have any program pages available for analysis, so the learning goals were listed either on the About Us page or a service-learning overview page.

Table 3. Learning goals and their frequency of occurrence by provider and the total number of programs in which the goal is mentioned

\begin{tabular}{|c|c|c|}
\hline Learning Goals & $\begin{array}{c}\text { Total } \\
\text { Providers }\end{array}$ & $\begin{array}{c}\text { Total } \\
\text { Programs }\end{array}$ \\
\hline Intercultural Competency & 4 & 10 \\
\hline Professional Skill Development & 3 & 7 \\
\hline Understanding Current Issues & 3 & 6 \\
\hline Global Citizenship & 4 & 6 \\
\hline Host Culture Knowledge & 4 & 6 \\
\hline Social Responsibility & 5 & 6 \\
\hline Community Development Principles & 2 & 4 \\
\hline Culturally Appropriate Responses & 3 & 3 \\
\hline Research Skills & 3 & 4 \\
\hline
\end{tabular}

Table 4. Learning goals matched with the providers that include the goals in their web content.

\begin{tabular}{|c|c|c|c|c|c|c|c|c|}
\cline { 2 - 9 } \multicolumn{1}{c|}{} & \multicolumn{7}{c|}{ Providers } \\
\hline Learning Goals & A & B & C & D & E & F & G & H \\
\hline Intercultural Competency & $\mathrm{x}$ & & $\mathrm{x}$ & $\mathrm{x}$ & & & & $\mathrm{x}$ \\
\hline Professional Skill Development & $\mathrm{x}$ & $\mathrm{X}$ & & $\mathrm{x}$ & & & & \\
\hline Understanding Current Issues & $\mathrm{x}$ & $\mathrm{X}$ & $\mathrm{x}$ & & & & & $\mathrm{x}$ \\
\hline Global Citizenship & & $\mathrm{X}$ & $\mathrm{x}$ & $\mathrm{x}$ & & & & $\mathrm{x}$ \\
\hline Host Culture Knowledge & & & $\mathrm{x}$ & $\mathrm{x}$ & & & & $\mathrm{x}$ \\
\hline Social Responsibility & $\mathrm{x}$ & $\mathrm{X}$ & & $\mathrm{x}$ & $\mathrm{x}$ & $\mathrm{x}$ & & \\
\hline Community Development Principles & $\mathrm{x}$ & & & $\mathrm{x}$ & & & & \\
\hline Culturally Appropriate Responses & & $\mathrm{x}$ & $\mathrm{x}$ & $\mathrm{x}$ & & & & \\
\hline Research Skills & $\mathrm{x}$ & & & $\mathrm{x}$ & & & & $\mathrm{x}$ \\
\hline
\end{tabular}




\section{Specifying Selection Criteria}

Only two providers, A and B, listed selection criteria specific to service-learning programs. In the case that a service-learning program was an add-on option for a traditional study abroad program, only selection criteria that went above and beyond the traditional study abroad admission standards was coded. Both providers A and B required a separate application for the service-learning program and specified minimum language proficiency for projects. Both providers also identified the need for enrolled students to obtain a police report before being allowed to participate in projects that involved working with children. Table 5 shows the list of criteria and the providers that cite those criteria.

Table 5. Selection criteria specific to service-learning projects by program provider

\begin{tabular}{|c|c|c|c|c|c|c|c|c|}
\cline { 2 - 9 } \multicolumn{1}{c|}{} & \multicolumn{7}{c|}{ Providers } \\
\hline Participation Criteria & A & B & C & D & E & F & G & H \\
\hline Language proficiency & $\mathrm{x}$ & $\mathrm{x}$ & & & & & & \\
\hline Minimum enrollment & $\mathrm{x}$ & & & & & & & \\
\hline Pre-approval from home university & $\mathrm{x}$ & & & & & & & \\
\hline Service-learning application & $\mathrm{x}$ & $\mathrm{x}$ & & & & & & \\
\hline Police report & $\mathrm{x}$ & $\mathrm{x}$ & & & & & & \\
\hline
\end{tabular}

\section{Describing Orientation or Training}

Four program providers included information in the analyzed content about preparing students for service-learning with a training or orientation (see Table 6). Providers A, D, G, and $\mathrm{H}$ mention an orientation that includes a cultural overview to prepare students for intercultural interactions. Providers A, D, and G reference an orientation specific to the service-project that may involve learning about the community partner, host community, project tasks, or target population. Only Provider A and Provider $\mathrm{H}$ specify that students will receive skills-related training to help them do the service project.

Table 6. Providers including information about orientation or training sessions to prepare students for the service-learning experience

(Topics described are categorized by cultural overview, service orientation, or skills training.)

\begin{tabular}{|c|c|c|c|}
\hline Provider & $\begin{array}{c}\text { Cultural } \\
\text { Overview }\end{array}$ & $\begin{array}{c}\text { Service } \\
\text { Orientation }\end{array}$ & $\begin{array}{c}\text { Skills } \\
\text { Training }\end{array}$ \\
\hline A & $\mathrm{x}$ & $\mathrm{x}$ & $\mathrm{x}$ \\
\hline $\mathrm{B}$ & & & \\
\hline C & & & \\
\hline D & $\mathrm{x}$ & $\mathrm{x}$ & \\
\hline E & & & \\
\hline F & & & \\
\hline G & $\mathrm{X}$ & $\mathrm{x}$ & \\
\hline H & $\mathrm{x}$ & & $\mathrm{x}$ \\
\hline
\end{tabular}




\section{Referencing Community Partner(s)}

Six providers refer to the role of community partners in the service project. Although five partners make general reference to working with community partners, using phrases such as "will work with a community partner" without identifying the specific partner, only three providers, C, D, and G, identify specific community partners by name. Table 7 shows this distribution and identifies the total number of programs that reference a community partner role. No provider referenced a community partner in every single program page.

Table 7. Providers referring to working with a community partner in their program pages, whether the reference is for general community partnership or identifies a specific partner; and the total number of programs analyzed for each provider

\begin{tabular}{|c|c|c|c|}
\hline Provider & $\begin{array}{c}\text { Programs that Name } \\
\text { Specific Partner }\end{array}$ & $\begin{array}{c}\text { Programs that Reference } \\
\text { Nonspecific Partner }\end{array}$ & $\begin{array}{c}\text { Total Programs } \\
\text { Analyzed }\end{array}$ \\
\hline A & 0 & 1 & 8 \\
\hline B & 0 & 1 & 9 \\
\hline C & 1 & 1 & 7 \\
\hline D & 5 & 6 & 14 \\
\hline G & 1 & 0 & 14 \\
\hline H & 0 & 1 & 6 \\
\hline
\end{tabular}

\section{Describing Service Projects}

In cases where providers include information about the intended service projects, most often they refer to a nonspecific project. Sometimes content includes a general reference with a phrase like "will complete a service project" although some providers may convey that projects are dependent upon the time of year or the community partner. In cases such as these, phrases such as "project details will be available closer to the program dates" or "projects will be defined based on community need" are used.

For program pages that reference community-defined needs, examples of the types of projects that may be offered are listed. Table 8 shows the categories of projects and the frequency with which they are mentioned by provider and program. Table 9 identifies which providers identify specific categories of projects.

Table 8. Categories of service projects described by providers, the total number of providers that offer that category of project, and total number of programs that include each category of project

\begin{tabular}{|c|c|c|}
\hline Service Project Categories & $\begin{array}{c}\text { Total } \\
\text { Providers }\end{array}$ & $\begin{array}{c}\text { Total } \\
\text { Programs }\end{array}$ \\
\hline Nonspecific Project & 5 & 20 \\
\hline Educational Activities & 4 & 8 \\
\hline Teaching English & 3 & 5 \\
\hline Construction & 1 & 4 \\
\hline Conservation & 1 & 4 \\
\hline Health and Wellness & 1 & 3 \\
\hline Animal Welfare & 1 & 1 \\
\hline Food Distribution & 1 & 1 \\
\hline Support for Refugees \& Asylum Seekers & 1 & 1 \\
\hline
\end{tabular}


Table 9. Categories of service projects described by providers and which categories of projects each provider offers

\begin{tabular}{|c|c|c|c|c|c|c|c|c|}
\cline { 2 - 9 } \multicolumn{1}{c|}{} & \multicolumn{7}{c|}{ Providers } \\
\hline Service Project Categories & A & B & C & D & E & F & G & H \\
\hline Nonspecific Project & $\mathrm{x}$ & $\mathrm{x}$ & $\mathrm{x}$ & $\mathrm{x}$ & & & & $\mathrm{x}$ \\
\hline Educational Activities & $\mathrm{x}$ & $\mathrm{x}$ & $\mathrm{x}$ & $\mathrm{x}$ & & & & \\
\hline Teaching English & $\mathrm{x}$ & $\mathrm{x}$ & & $\mathrm{x}$ & & & & \\
\hline Construction & & & & $\mathrm{x}$ & & & & \\
\hline Conservation & & & & $\mathrm{x}$ & & & & \\
\hline Health and Wellness & & & & $\mathrm{x}$ & & & & \\
\hline Animal Welfare & & & $\mathrm{x}$ & & & & & \\
\hline Food Distribution & $\mathrm{x}$ & & & & & & & \\
\hline Support for Refugees \& Asylum Seekers & $\mathrm{x}$ & & & & & & & \\
\hline
\end{tabular}

\section{Benefit to Community Partner(s)}

Only three providers, Providers D, F, and H, articulate how their service-learning programs benefit their host communities. Providers F and $\mathrm{H}$ do not provide specific project information but instead, in their About Us pages, mention the existence of a fund that issues grants or scholarships to their host communities. Provider D, which also offers a grant fund to host communities, lists project-specific benefits for each of its 14 programs. The benefits fall into five categories as illustrated in Figure 1. As the only provider to specifically mention benefits to community partners for individual programs, the data available in Figure 1 are specific to Provider D.

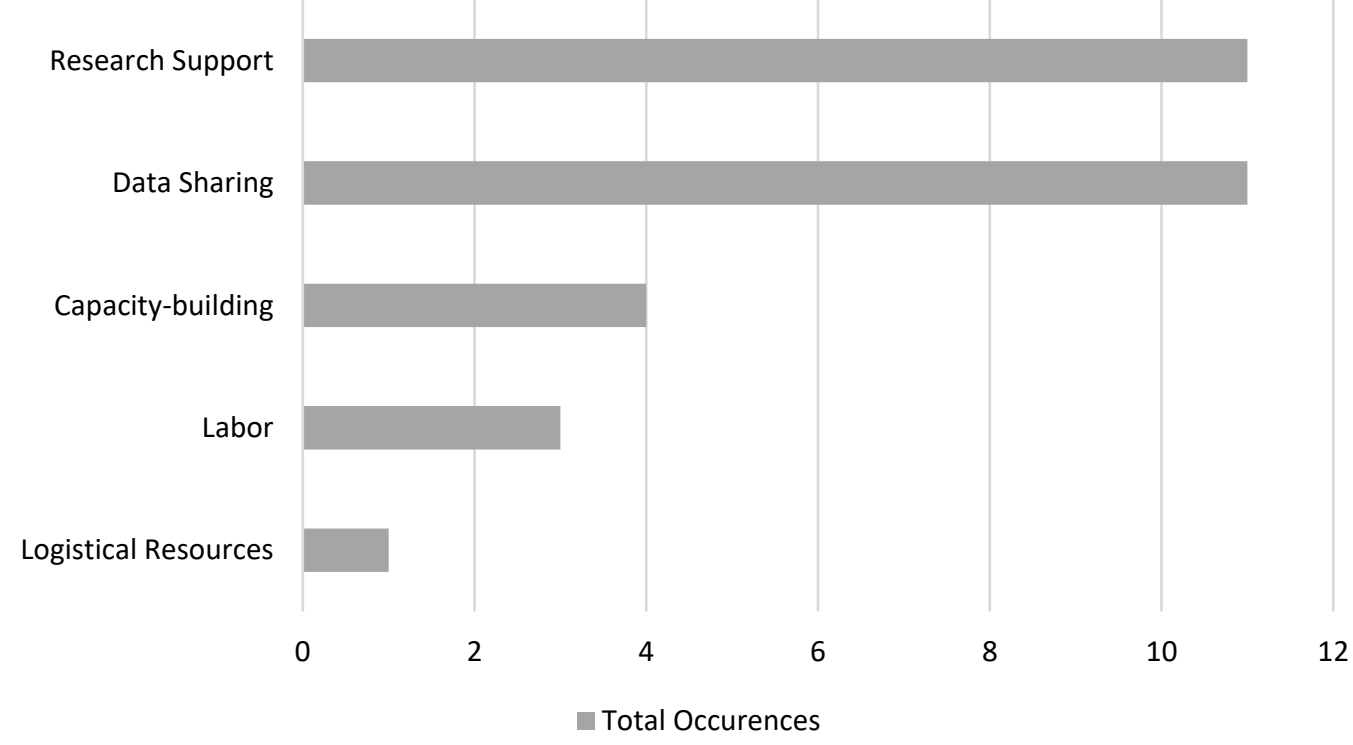

Figure 1. Types of benefits mentioned for community partners as service partners as well as the frequency of their occurrence*

Because only one provider, Provider D, articulates benefits for each service-learning program in their program pages, these data are only representative of Provider $D$. 


\section{Describing the Context of Service}

Although each provider includes descriptions of the geographic landscape of host communities, only one provider, Provider D, includes information about the context of service that includes a history of the community, the people in the community, and/or the community's needs. Provider D also, in some instances, includes a history of its relationship with its partners or host communities.

\section{Articulation of Project Goals and Outcomes}

Only Provider D listed goals and outcomes for the partner agencies or host communities in its program pages. The types of goals and outcomes, as well as the frequency with which they appear in different programs, are listed in Table 10.

Table 10. Categories of goals and outcomes described by Provider D, as well as the frequency with which they appear in programs*

Only Provider D identified project goals and outcomes which is why the data represents only Provider D.

\begin{tabular}{|c|c|}
\hline Goals and Outcomes for Host Community or Partner(s) & $\begin{array}{c}\text { Total } \\
\text { Programs }\end{array}$ \\
\hline Conservation & 10 \\
\hline Educational Gains & 8 \\
\hline Health and Wellness Gains & 7 \\
\hline Professional Skills Development \& Increased Employability & 7 \\
\hline General Community Development & 6 \\
\hline Scientific Knowledge Advancement & 5 \\
\hline Personal and Social Development & 4 \\
\hline Infrastructure Improvement & 3 \\
\hline Language Skills Development & 3 \\
\hline Intercultural Competency Skill Development & 1 \\
\hline
\end{tabular}

\section{Language Used to Describe Service Partnerships and Target Populations}

In addition to capturing the types of information providers offer about their service-learning programs, this analysis included language that providers use to describe their partnerships. The most commonly used words, as illustrated in Figure 2, were "contribute," followed by “collaborative" and "help.” References to the service relationship were only counted on 7 of the 70 total program pages analyzed, which means that only $10 \%$ of the analyzed programs included language to characterize the nature of service partnerships with host communities. The size of the word cloud in Figure 2 is reduced to represent the absence of references to community partners across $90 \%$ of the analyzed content.

When referring to target populations for service projects, providers use a variety of phrases and terms. Sometimes the community at large is described as the target population, in which case providers use terms like "local community," although "villagers" and "host location" were also identified. 


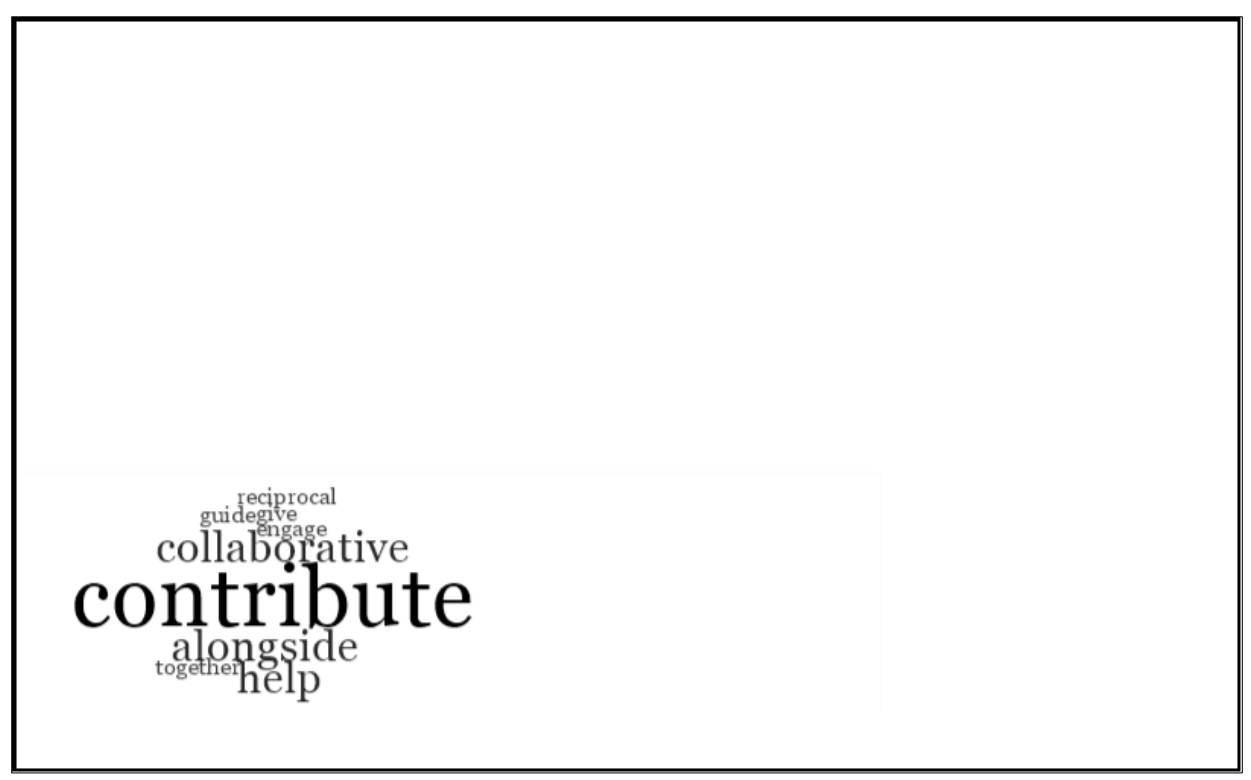

Figure 2. Word Cloud

This word cloud illustrates the words providers use to describe their partnerships with community partners and the frequency with which they occur. Only $10 \%$ of the analyzed pages included language to characterize the nature of service partnerships with host communities, and the size of the word cloud in Figure 2 is reduced to represent the absence of references to community partners across the vast majority of the analyzed content.

When referring to specific populations, providers used a variety of descriptors to refer to people by a specific characteristic. The terms have been categorized into types of populations: people with low incomes, people with mental illness, people with disabilities, and other (see Table 11). Of the 70 total pages analyzed, 22 program pages, or $31 \%$ of the sample, offered some language describing target populations of service.

Table 11. This table shows the phrases used to describe target populations for service projects

\begin{tabular}{|c|c|}
\hline Population & Descriptors \\
\hline Community at Large & $\begin{array}{ll}\text { - } & \text { local community members } \\
\text { - } & \text { local community } \\
\text { - } & \text { community } \\
\text { - } & \text { children in the local community } \\
\text { - } & \text { locals } \\
\text { - } & \text { villagers } \\
\text { - } & \text { host location } \\
\end{array}$ \\
\hline People with Low Incomes & $\begin{array}{ll}\text { - } & \text { young learners from disadvantaged backgrounds } \\
\text { - } & \text { underprivileged individuals } \\
\text { - } & \text { local disadvantaged children } \\
\text { - } & \text { less advantaged people } \\
\end{array}$ \\
\hline People with Mental Illness & - mentally ill adults \\
\hline People with Disabilities & $\begin{array}{ll}\text { - } & \text { the mentally disabled } \\
\text { - } & \text { people with intellectual disabilities } \\
\text { - } & \text { disabled }\end{array}$ \\
\hline Other & $\begin{array}{ll}\text { - } & \text { women } \\
\text { - } & \text { children } \\
\text { - } & \text { elderly } \\
\text { - } & \text { immigrants }\end{array}$ \\
\hline
\end{tabular}




\section{Discussion}

This analysis is conducted through the lens of two ethical guidelines for international service-learning:

- Prioritize human dignity and community autonomy such that educational agendas of the student or the home institution are not prioritized over community safety, autonomy, and dignity.

- Recognize the risk of paternalism, exploitation, and neocolonial behavior on behalf of institutions/organizations from resource-rich environments when engaging with partners in low material resource settings (Guidelines, 2018).

With six of the eight providers included in this study identifying ethical practice as a priority for their organizations (

Table 2), this lens is appropriate for analyzing their content.

\section{Prioritizing Human Dignity}

The way providers reference and describe target populations can have a significant impact on upholding the dignity of the people who fall into those respective populations. Error! Reference source not found. lists the descriptive terms providers used when talking about the people who would be served in the projects. When providers made references to the community at large, using phrases such as "local community members" or "children in the local community," the term was typically linked to a specific project description such as conducting sports clinics for kids, delivering skills workshops, or sharing information from research. In so doing, the people of the community were not defined by a deficit or a need. Instead, the project was defined, while the people were not.

When terms defined target populations by a specific characteristic, such as "underprivileged individuals," "the mentally disabled," or "elderly," the people were lost to the characteristic used to define them. This dilution of personhood is exacerbated by the absence of accompanying project descriptions. Where these kinds of descriptions occur, the people themselves are the project description. Phrases such as "will work with the mentally disabled" or "will work with women, children, elderly, disabled, or immigrants" where no actual project is defined implies that there is no specific need to be addressed, but that the target population's existence is, itself, the need. This type of language not only undermines the dignity of the people involved in the service but also feeds paternalistic perspectives on service to marginalized populations.

\section{Prioritizing Community Autonomy}

The way communities are represented in content about their own communities can be an important reflection of the way providers value autonomy when service projects and partnerships are designed and implemented. The results of this study reveal that host communities are largely absent from content about service-learning study abroad programs. Only one provider, Provider D, described their host communities or community partners. When Provider D supplies information about community assets, context of the community need being addressed, and the history of partner organizations in addressing those needs, Provider D contributes to the portrayal of the hosts as a dynamic group of people who are actively engaged in addressing their own needs 
An important strategy for enhancing community autonomy is to provide space for a community to speak for itself. None of the content analyzed in this study included voices from community partners or people in the host communities. The existing content was presented exclusively from the perspective of the provider. Even though projects may be described as community-defined, community autonomy is undermined when the community does not speak for itself. This can be especially troublesome when defining project goals. When Provider D defines community impact goals ( Table 10), it is not always clear whether the goals are community-defined, partner-defined, or provider-defined. While it is appropriate for providers to define their own project goals, clearly defining the originators of goals can further reinforce community autonomy. What would be ideal, however, would be inclusion of community-defined goals alongside provider-defined goals. By only listing provider goals, even if they are defined as such, providers risk undermining autonomy and reinforcing paternalistic attitudes about doing service.

\section{Recognizing the Risk of Paternalism, Exploitation, and Neo-Colonial Behavior}

When seven out of eight providers do not include any information about their host communities in their program content, they render those communities invisible. It can be difficult to communicate values of dignity and autonomy for communities affected by service projects when their existence is not being acknowledged. This invisibility is also evident when comparing the frequency with which providers describe their relationship with their community partners (see Figure ) with the number of times providers describe their target populations (see

Table 11). Only $10 \%$ of the sampled program pages included details characterizing the relationship between provider and community partner when compared with $31 \%$ of the program pages including information about target populations. This imbalance suggests a primary focus on what will be done and a devaluation of how it will be done.

Not including information about host communities or how they are affected by service-learning projects can reinforce the idea that any help is good help without regard to actual need, cultural context, or the impact of outside intervention on the people and communities being targeted. This idea is further reinforced by the absence of emphasis on either selection criteria (

Table 5) or training (Table 6) for projects that may require specialized skills or expertise. Error! Reference source not found. and Table 9 list the nine identified categories of projects, some of which are actually credentialed professions like teaching English, while others may require heightened communication skills such as language proficiency. Although providers may be offering excellent trainings to equip students with the skills necessary to be effective in their roles, by not including these details, they imply that anyone who enrolls in the program will be effective in their service role.

This approach is the essence of the Great Savior mentality that has come under fire in recent years because of its paternalistic assumptions. The less detail providers offer about the service projects and partners - who they are serving, why they are serving, how they are serving - even at the recruitment stage, the more they contribute to the larger problem of students seeking service for service's sake. By including community partner 
and host community information that frames the service-learning projects within the larger community context, providers have the opportunity to challenge problematic notions of international service while simultaneously demonstrating to more savvy prospective clients that they are committed to ethical engagement.

\section{Conclusions, Limitations, and Further Study}

The results of this study did not meet expectations. In light of the level of criticism levied at the international volunteerism industry, we anticipated encountering problematic language that aligned with criticisms. Discovering an absence of language or information, however, was surprising. Although this is troublesome when thinking about communicating information in a way that upholds dignity and autonomy and challenges paternalism and neocolonialism, it seems a problem more easily remedied than having to rewrite content. The prevalence of ethical practice as a priority throughout these providers' websites (

Table 2), as well as the articulated student learning goals focusing on social responsibility and intercultural competency, leave us hopeful that the ethical guidelines that framed this analysis will be valued by service-learning study abroad program providers.

There were limitations to this study. Only public-facing web content was analyzed, so any information that students receive upon enrollment or upon in-country arrival was not considered. This study also did not include syllabi, which may provide additional context for service projects. Further research should include these types of materials as well as investigate how providers design their content and how potential students' expectations and evaluation of programs is impacted by the type of information provided on these webpages.

\section{Acknowledgment}

Thank you to Dr. Julie Strecker (Mercer University), Dr. Mary Alice Morgan (Mercer University), and Dr. Michele Prettyman Beverly (Fordham University) for support.

\section{References}

Bamber, P.M. \& Pike, M. (2013). Towards an ethical ecology of international service learning. Journal of Curriculum Studies, 45(4), 535-559. https://doi.org/10.1080/00220272.2012.675354

Barbie Savior [@barbiesavior]. (2019, March 13). Instagram photographs. Retrieved December 11, 2019 from, https://www.instagram.com/p/Bq-A-dvBLiH/

Chieffo, L. \& Spaeth, C. (2017). Guide to successful short-term programs abroad (3rd ed.). Washington, D.C.: NAFSA - Association of International Educators.

Dixon, B. (2015). International service learning: Analytical review of published research literature. The Forum on Education Abroad. 107-131.

Goodwin, H. (2015). Tourism, good intentions, and the road to hell: Ecotourism and volunteering. Brown Journal of World Affairs, 22(1), 37-50.

Guidelines for community engagement, service-learning, and volunteer experiences abroad. (2018). The Forum on Education Abroad. Retrieved from https://forumea.org/wpcontent/uploads/2018/03/Guidelines-for-Community-Engagement-P4.pdf

Haile, T. (2014, March 9). What you think you know about the web is wrong. Time. Retrieved from https://time.com/12933/what-you-think-you-know-about-the-web-is-wrong/

Hains-Wesson, R. (2017). Why aren’t we talking? Third-party providers and mobility programs. Higher Education Research \& Development, 36(4), 866-869. https://doi.org/10.1080/07294360.2017.1284033 
Hains-Wesson, R. \& Appleby, M. (2017) A perspective on third-party providers and study tour programs: A mixed method study. Issues in Educational Research, 27(3), 435-452.

Hartman, E., \& Kiely, R. (2014). Pushing boundaries: Introduction to the global service-learning special section. Michigan Journal of Community Service Learning, 21, 55 - 63.

Hernandez-Maskivker, G., Lapointe, D., \& Aquino, R. (2018). The impact of volunteer tourism on local communities: a managerial perspective. International Journal of Tourism Research, 20, 650-659. https://doi.org/10.1002/jtr.2213

Heyl, J.D. (2011). Third-Party Program Providers and Education Abroad: Partner or Competitor? AIEA Occasional Paper. Retrieved from

https://www.aieaworld.org/assets/docs/OccasionalPapers/third\%20party\%20providers-\%20heyl-\%20 op.pdf

Humanitarians of Tinder. (n.d.) Retrieved December 11, 2019, from https://humanitariansoftinder.com/image/152318000859

Kurtzman, R. (2017). Working with a program provider or other outside organization. In L. Chieffo \& C. Spaeth (Eds.), The Guide to Successful Short-Term Programs Abroad (3rd ed., pp 195-214). Washington, D.C.: NAFSA - Association of International Educators.

Melles, G. (2018). Sustainable community development or voluntourism: Sustainable housing in rural Maharashtra. Social Sciences, 7, 247-260. https://doi.org/10.3390/socsci7120247

QUIP: Recognition. (n.d.) Retrieved September 21, 2019, from https://forumea.org/get-involved/qualityassurance-programs/quip/institutions-and-organizations-recognized-for-meeting-the-standards/

Rhodes, G., Loberg, L., \& Hubbard, A. (2014). Historical, philosophical, and practical issues in providing global learning opportunities through study abroad. In A. Highum (Eds), Undergraduate Global Education: Issues For Faculty, Staff, And Students (pp. 5-13). Hoboken, NJ: John Wiley \& Sons, Inc.

Schwarz, K.C. \& Richey, L.A. (2019). Humanitarian humor, digilantism, and the dilemmas of representing volunteer tourism on social media. New Media \& Society, 21(9), 1928-1946. https://doi.org/10.1177\%2F1461444819834509

Sin, H.L. \& He, S. (2019) Voluntouring on Facebook and Instagram: Photography and social media in constructing the 'Third World' experience. Tourist Studies, 19(2), 215-237. https://doi.org/10.1177/1468797618815043

Standards of Good Practice for Education Abroad. (2015). The Forum on Education Abroad. Retrieved from https://forumea.org/wp-content/uploads/2014/08/Standards-2015.pdf

State of the Field 2017. (2018). The Forum on Education Abroad. Retrieved from https://forumea.org/wpcontent/uploads/2018/03/ForumEA-State-of-the-Field-18-web-version.pdf

Steele, J. \& Dredge, D. (2017). The liquid organization of volunteer tourism: Implications for responsibility. International Journal of Tourism Research, 19, 715-726. https://doi.org/10.1002/jtr.2143

\section{Author Biographies}

Hannah Vann Nabi is the Associate Director of Research that Reaches Out at Mercer University. Her work focuses on service-learning and the integration of undergraduate research and service.

Dr. Pam Estes Brewer teaches Technical Communication at Mercer University. She is a Fellow in the Society for Technical Communication and a member of IEEE Professional Communication Society. She has published two books, International Virtual Teams: Engineering Global Success and a 2nd edition of A Research Primer for Technical Communication with George Hayhoe. She is incoming chair of the Department of Technical Communication. 